\title{
PENGARUH KECANDUAN MEDIA SOSIAL TERHADAP PRESTASI BELAJAR MAHASISWI ASRAMA DI SEKOLAH TINGGI FILSAFAT JAFFRAY MAKASSAR
}

\author{
Sari Jani, Ivan Th. J. Weismann
}

\begin{abstract}
Abstrak
Tujuan penulisan dari skripsi ini adalah, untuk mengetahui pengaruh kecanduan media sosial dalam asrama dan memberikan hasil penelitian pengaruh kecanduan media sosial terhadap prestasi belajar. Adapu metode penelitian yang digunakan dalam penulisan skripsi ini adalah dengan menggunakan metode kuantitatif. Dan untuk melakukan penelitian tersebut hal yang dilakukan, yaitu: Pertama, pengambilan dan pengumpulan data melalui buku, jurnal, dan skripsi online yang berkaitan dengan judul yang dibahas dalam skripsi ini. Kedua, observasi lapangan dan menyebarkan angket tertutup kepada mahasiswi sebagai responden. Ketiga, wawancara langsung kepada mahasiwi. Kesimpulan dari penulisan ini, ialah: Pertama, Seseorang yang sudah kecanduan media sosial akan sulit untuk lepas karena sudah menjadi sutu kegemaran dan tidak nyaman jika tidak bermain media sosial. Kedua, prestasi belajar adalah sesuatu yang telah dicapai, dan diperoleh dalam mengikuti proses belajar. Ketiga, dari hasil koefisien korelasi antara kecanduan media sosial terhadap prestasi belajar adalah 0,661 berarti kedua variabel tersebut memiliki hubungan yang sangat kuat. Dan konstribusi kecanduan media sosial memberikan pengaruh pada prestasi belajar sebesar $65 \%$ yaitu sangat kuat.
\end{abstract}

Kata-Kata Kunci: Media sosial, Kecanduan, Prestasi belajar, Mahasiswa asrama, STF Jaffray.

\section{Pendahuluan}

\section{Latar Belakang Masalah}

Era globalisasi yang modern membawa banyak perubahan terutama dalam kehidupan manusia. Hal ini dapat dilihat melalui perkembangannya internet dengan banyaknya media sosial. Media sosial memudahkan setiap orang untuk mengakses apa saja dengan mudah dan cepat. Dan tanpa disadari bahwa media sosial dapat memengaruhi seluruh aspek kehidupan seseorang

Di abad ke-21, pengguna internet dan masyarakast luas masih mengidentikkannya sebagai "alat" komunikasi yang biasa-biasa saja. Berbeda dengan zaman sekarang, internet menjadi "media" tersendiri yang bahkan mempunyai kemampuan interaktif bagi manusia. Aspek tersebut telah melahirkan ekstra kemudahan bagi para penggunanya. ${ }^{1}$ Oleh karena itu,

\footnotetext{
${ }^{1}$ Ditha Pransanti, "Perubahan Media Komunikasi Dalam Pola Komunikasi Keluarga Di Era Digital," Commed: Jurnal Komunikasi Dan Media 1, no. 1 (17 Juli 2017): 70, diakses 28 Februari 2019, http://ejournal.upbatam.ac.id/index.php/commed/article/view/115.
} 
dengan adanya perubahan pola pikir mengenai internet maka pengguna internet pun meningkat dengan pesat.

Perkembangan teknologi juga memengaruhi seseorang dalam menggunakan media sosial. Hal ini dapat dilihat karena teknologi internet memudahkan orang untuk mencari sebuah data, hiburan, untuk berkomunikasi, dan menolong orang untuk bisa berbinis online yang tidak dibatasi oleh jarak dan waktu lewat media sosial. Media sosial juga mempunyai pengaruh yang cukup besar dalam perkembangan teknologi komunikasi yang di mana kebanyakan remaja maupun orang dewasa lah yang sering memakai atau menggunakan media sosial tersebut. ${ }^{2}$ Bahkan tidak menutup kemungkinan bahwa pada masa sekarang anak-anak juga terlibat dalam penggunaan internet.

Dilaporkan kini terdapat 640 juta pengguna jaringan aktif di seluruh dunia; ada 50 miliar foto yang diunggah ke dunia maya, sedangkan pengguna internet yang tercatat di seluruh dunia kini telah mencapai 2 miliar. Indonesia menduduki urutan kedua dalam catatan pengguna Facbook terbanyak, dan urutan pertama dalam penggunaan Twiiter. Sampai dengan tahun 2010 di Indonesia tercatat ada 57,8 juta pengguna internet dengan prediksi akan menjadi 175 juta pada tahun $2020 .^{3}$

Melihat perkembangan media sosial yang semakin menjadi sebuah tren dalam kehidupan manusia membuat setiap orang untuk lebih banyak menghabiskan waktu mereka dengan menggunakan media sosial yang mereka miliki, sehingga inilah yang membuat kebanyakan orang untuk tidak bisa berkembang karena mereka hanya memuaskan diri mereka sendiri.

Hal ini dilihat dari "hadirnya media sosial di internet membuat masyarakat untuk lebih aktif dalam mengakses internet, di mana mereka lebih mudah untuk membaca berita terbaru, dan cepat untuk memberikan tanggapan isu-isu publik yang terjadi. ${ }^{4}$

Secara umum remaja dan orang dewasa lebih banyak menggunakan media sosial handphone sebagai sarana komunikasi yang bisa mengubah perilaku komunikasi mereka dan cenderung dari remaja dan kaum muda sudah dikontrol dengan adanya alat komunikasi ini. Sehingga bukan lagi mereka yang mengontrol tetapi merekalah yang dikontrol oleh teknologi.

Meskipun begitu, media sosial juga menjadi sebuah kebutuhan yang sangat diperlukan bagi setiap orang. Melalui manfaat sosial media menolong orang untuk bisa berkomunikasi dengan orang yang memiliki jarak yang jauh, dan menolong seseorang untuk bisa memperoleh pengetahuan baru ketika mereka mencari sebuah informasi yang belum mereka ketahui.

Setiap orang sudah dipengaruhi oleh sosial media yang di mana ini menjadi suatu kebutuhan oleh banyak orang. Sosial media sendiri sudah menjadi sebuah kebutuhan primer bagi kehidupan banyak orang, karena banyak orang pada masa sekarang yang dalam aktifitasnya sehari-hari lebih fokus pada internet media sosial.

Seseorang bisa dikatakan kecanduan internet jika penggunaannya bisa lebih dari tiga puluh menit dalam sehari atau dilihat dari frekuensinya maka penggunaannya bisa lebih dari tiga kali dalam sehari (Ma'rifatul Laili \& Nuryono, 2015). Sedangkan menurut penelitian

\footnotetext{
${ }^{2}$ Rizky Ramanda Gustam, “Karakteristik Media Sosial Dalam Membentuk Budaya Populer Korean Pop di Kalangan Komunitas Samarinda dan Balikpapan,” eJournal Ilmu Komunikasi 3, no 2 (2015): 19, diakses 23 Mei 2019, https://ejournal.ilkom.fisip-unmul.ac.id/site/?p=1806.

${ }^{3}$ Chou Hellen Pratama, Cyber Smart Parenting (Bandung: Visi Anugerah Indonesia, 2012), 43.

${ }^{4}$ Hasanuddin, dkk, Anxieties/Desires (Jakarta: Gramedia Pustaka Utama, 2011), 258.
} 
yang dilakukan oleh Markeeters pada tahun 2013, hampir $70 \%$ pengguna internet di Indonesia berusia lima belas sampai usia dua puluh dua tahun menghabiskan waktu lebih dari tiga jam sehari menggunakan internet. Tiga hal utama yang dilakukannya adalah mengakses media sosial 94\%, mencari info 64\% dan membuka email 60,2\% (Santika, 2015). ${ }^{4}$

Seseorang yang sudah terbiasa dalam mengakses internet lebih dari waktu tiga puluh menit dalam sehari, dapat dikatakan bahwa seseorang itu sudah kecanduan internet. Seseorang yang sudah sering menggunakan internet media sosial ini adalah remaja akhir termasuk mahasiswi di mana mereka membuka situs-situs dalam media sosial yang dapat menghibur.

Terkait dengan adanya penggunaan media sosial sebagai sebuah sarana hiburan, di dalam kehidupan mahasiswi berasrama di kampus Sekolah Tinggi Filsafat Jaffray Makasar. Sudah menjadi sebuah masalah yang membuat kehidupan mahasiswi asrama untuk sering menghabiskan waktu dalam bermain internet. Mereka lebih banyak melihat situs-situs internet dengan menonton drama korea, bermain Fecebook, bermain Instagram, membaca novel, membaca komik, bermain game online dan hal-hal yang bersifat menghibur. Sehingga membuat mereka lebih sering menghabiskan waktu mereka bermain media sosial, dari pada menghabiskan waktu untuk mengerjakan tugas-tugas kuliah. Ini lah akhirnya menyebabkan sebuah prestasi belajar mahasiswi menurun.

Berbicara tentang prestasi belajar menurut Nasution, (1987) prestasi belajar adalah kesesuaian yang dicapai peserta didik dalam hal memahami, merenung dan melakukan persiapan belajar, yang apa bila dikatakan prestasi belajar mencapai kesesuaian bila mencapai 3 aspek belajar yakni ranah kognitif, ranah afektif dan ranah psikomotorik. $^{5}$

Dengan melihat tiga aspek yang disebut ranah kognitif, ranah afektif, dan ranah pskikomotorik, ketika mahasiswi tidak mempunyai ketiga ranah ini maka seseorang itu tidak akan mencapai sebuah prestasi yang baik. Karena hanya menggunakan salah satu ranah tersebut, atau hanya menggunakan ranah kognitif dan ranah afektif sehingga seseorang bisa diakatan tidak berhasil dalam mencapai sebuah prestasi.

Penggunaan internet yang benar dan tepat tentu akan memberikan sebuah dampak postif bagi mahasiswi dalam mencapai suatu prestasi yang baik. Mahasiswi dituntut untuk mandiri dalam proses belajarnya dan lebih memotivasi dalam bertanggung jawab terhadap keterampilan belajar. Mahasiswi juga harus berbekal pengguasaan dalam mengelola, dan memanfaatkan informasi seefektif mungkin dalam proses belajarnya menggunakan media sosial. $^{6}$

Pengunaan media sosial yang benar akan menolong khususnya dalam perkuliahan, untuk mencari bahan-bahan tugas yang diberikan oleh dosen yang mengharuskan terhubung

\footnotetext{
${ }^{4}$ Ayu Permata Sari, Asmidir Ilyas, dan Ifdil, “Tingkat Kecanduan Internet Pada Remaja Awal,” JPPI (Jurnal Penelitian Pendidikan Indonesia) 3, no. 2 (31 Desember 2017): 45, diakses 20 Mei 2019, https://doi.org/10.29210/02018190. Ayu Permata Sari, Asmidir Ilyas, dan Ifdil mengutip Ma'rifatul Laili, F., dan Nuryono, W. "Penerapan Konseling Keluarga Untuk Mengurangi Kecanduan Game Online Pada Siswa Kelas VII SMP Negeri 21 Surabaya.” Jurnal BK 5, no. 1 (2015), 65-72.

${ }^{5}$ Nadya Rismawati dan Gida Kadarisma, "Analisis Motivasi Belajar Terhadap Prestasi Belajar Matematika Siswa SMP," Journal On Education 1, no. 2 (2018): 493, diakses 28 Januari 2019, http://jonedu.org/index.php/joe/article/view/102. Nadya Rismawati dan Gida Kadarisma, mengutip Nasution, Berbagai Pendekatan Dalam Proses Belajar Mengajar (Jakarta: Bina Aksara, 1987).

${ }^{6}$ Eti Nurhayati, Psikologi Pendidikan Inovatif (Yogyakarta: Pustaka Pelajar, 2011), 44.
} 
ke internet. Sehingga dengan adanya penggunaan media sosial sebenarnya akan sangat membantu mereka untuk bisa meningkatkan prestasi belajar mahasiswi.

Dengan adanya permasalahan tersebut maka penulis ingin membahas kecanduan media sosial terhadap mahasiswi. Oleh karena itu, penulis akan meneliti dan menulis skripsi dengan judul PENGARUH KECANDUAN MEDIA SOSIAL TERHADAP PRESTASI BELAJAR MAHASISWI ASRAMA DI SEKOLAH TINGGI FILSAFAT JAFFRAY MAKASSAR.

\section{Pokok Masalah}

Dengan melihat latar belakang masalah di atas, maka pokok masalah dalam penulisan skripsi ini adalah: Sejauh mana pengaruh kencanduan media sosial terhadap prestasi belajar mahasiswi asrama di kampus Sekolah Tinggi Filsafat Jaffray Makassar?

\section{Tujuan Penelitian}

Adapun yang menjadi tujuan dalam penulisan skripsi ini adalah untuk mengetahui pengaruh kencanduan media sosial dalam asrama dan memberikan hasil penelitian pengaruh kecanduan media sosial terhadap prestasi belajar

\section{Manfaat penelitian}

Pertama, menambahkan wawasan penulis tentang cara menulis dan penelitian lapanagan yang baik.

Kedua, diharapkan penulisan ini dapat menjadi bahan bacaan untuk menmambah ilmu bagi penulis dan pembaca.

Ketiga, untuk memenuhi suatu syarat dalam menyelesaikan Strata Satu (S-1), Program Studi Teologi Kristen Pada Sekolah Tinggi Teologi Jaffray Makassar.

\section{Metode penelitian}

Dalam penelitian ini menggunakan metode kuantitatif dengan teknik pengumpulan data sebagai berikut: ${ }^{7}$

Pertama, studi kepustakaan mengumpulkan sumber informasi melalui buku-buku dan sumber lainnya yang berhubungan dengan pokok bahasan.

Kedua, mengadakan angket penelitian data langsung dari sumber informasi disusun sesuai dengan materi yang masih relevan dengan pokok pembahasan.

\section{Batasan Penelitian}

Dalam penulisan penelitian ini, memfokuskan pada suatu topik pengaruh media sosial terhadap prestasi belajar mahasiswi asrama di kampus Sekolah Tinggi Teologia Jaffray Makassar

\section{Sitematika penulisan}

Dalam penulisan penelitian ini terbagi kedalam beberapa bab dengan sistematika penulisan sebagai berikut:

Bab I, membahas pendahuluan yang didalamnya mencakup latar belakang masalah, pokok masalah, tujuan penulisan, manfaat penulisan, metode penelitian, batasan penulisan dan sistematika penulisan.

\footnotetext{
${ }^{7}$ Hasmawaty, 55; Sareong dan Supartini, 29; Serli dan Wijaya, 17.
} 
Bab II, merupakan pembahsan mengenai tinjauan pustaka yang menjesakan beberapa pokok dalam pembahasan sehubungan dengan topik penulisan skripsi. Bagian pertama membahas tentang definisi, sejarah, ciri-ciri, jenis-jenis,tipe pengguna, dampak positi, dan dampak negatif media sosial. Bagian kedua, membahas tantang definisi, kecanduan,jenisjenis dan Kriteria Kecanduan media sosial, Bagian ketiga, membahas tantang definisi dan faktor yang mempengaruhi prestasi belajar.

Bab III, membahas tentang gambaran umum lokasi penelitian, jenis penelitian, teknik pengumpulan data, dan teknik analisis data. Bagian pertama membahas tentang gambaran umum lokasi penelitian yaitu Sekolah Tinggi Filsafat Jaffray Makasar secara letak geografis, visi dan misi sekolah. Kedua, membahas mengenai jenis penelitian yang digunakan yaitu peneltian kuantitatif, populasi, dan sampel. Ketiga, membahas mengenai teknik pengumpulan data yang terdiri dari kajian pustaka, angket, wawancara yang dilanjutkan juga dengan teknik analisis data.

Bab IV, membahas tentang analisis hasil penelitian dan pembahasan.

Bab V, merupakan penutup yang terdiri dari kesimpulan dan saran.

\section{Kesimpulan}

Dari hasil analisis yang telah dilakukan oleh penulis dalam penelitian ini, maka dapat ditarik kesimpulan sebagai berikut:

Pertama, dari hasil perhitungan menggunakan model backward chaining dari 10 reponden yang tidak kecanduan media sosial ada 4 responden dimana memiliki 1 indikator atau kriteria kecanduan media sosial. Yang berada pada Penggunaan waktu berlebihan, mengabaikan kehidupan sosial dan tergangunya pola tidur. Sedangkan prestasi dan IPK prestasi belajar memiliki nilai yang baik.

Kedua, dari hasil menggunakan model backward chaining dari 10 reponden yang kecanduan media sosial ada 6 responden dimana memiliki 2 samapi 4 indikator atau kriteria kecanduan media sosial. Yang berada pada "Penggunaan waktu berlebihan, mengabaikan perkerjaan, ketidak mampuan mengontrol diri, pemborosan menggunakan uang dan mengabaikan kehidupan sosial dan tergangunya pola tidur." Sedangkan prestasi belajar dan IPK memiliki nilai yang baik

Ketiga, dari hasil korelasi antara kecanduan medai sosial terhadap prestasi belajar adalah 0,661 berarti kedua variabel tersebut memiliki hubungan yang sangat kuat. kecanduan media sosial memberikan pengaruh pada prestasi belajar sebesar $65 \%$. Jadi dapat dikatakan bahwa kecanduan media sosial memiliki penagruh yang sangat kuat pada prestasi belajar.

\section{Saran-saran}

Pertama, dalam penelitian ini diiharapkan kepada mahasiswi asrama putri agar lebih bijak lagi dalam menggunakan media sosial dan dapat menggunakan sesuai dengan kebutuhan.

Kedua, diharapkan kepada orang tua, dosen, dan karyawan untuk memberi nasehat, teguran dan perhatian khusus kepada mahasiswi.

Ketiga, diharapkan kepada pihak-pihak mahasiswi, kampus, yang akan melakukan penelitian pengaruh kecanduan media sosial terhadap prestasi belajar agar lebih mendalami penelitian yang dilakukan.

Keempat, diharapkan kepada seluruh mahasiwi yang akan melakaukan penelitian dengan judul penulisian pengaruh kecanduan media sosial terhadap prestasi belajar yang 
sama diharapkan agar bisa melengkapi lagi sumber-sumber dan dapat digunakan dengan baik.

\section{Kepustakaan}

Adrianus, Beni, Daniel, Elga, Enda, Fadjroel, Hafiz, dkk. Social Media Nation. Jakarta: Prasetiya Mulya, 2013.

Ali. Penelitian Kependidikan. Bandung: Angkasa, 1981.

Amiluddin, Risnawati, dan Sugiman Sugiman. "Pengaruh Problem Posing dan PBL Terhadap Prestasi Belajar, dan Motivasi Belajar Mahasiswa Pendidikan Matematika." Jurnal Riset Pendidikan Matematika 3, no. 1 (8 Mei 2016): 100-108. Diakses 18 Juli 2019. https://doi.org/10.21831/jrpm.v3i1.7303.

Anwar, Fahmi. "Perubahan Dan Permasalahan Media Sosial." Jurnal Muara Ilmu Sosial, Humaniora Dan Seni 1, no. 1 (10 Mei 2017). 137. Diakses 22 Mei 2018. https://doi.org/10.24912/jmishumsen.v1i1.343.

Arifah Nur. Panduan Lengkap Menyususn Dan Menulis Skripsi, Tesis, Dan Disertasi Lengkap Dengan Teknik Jitu Menyusun Proposal Agar Segera Disetujui. Yogyakarta: Araska, 2018.

Ariyanto, Anang. "Hubungan Antara Kontrol Diri Dengan Kecanduan Internet Pada Remaja Di Surakarta. Diakses 30 Agustus 2019. https://docplayer.info/90819200Hubungan-antara-kontrol-diri-dengan-kecanduaninternet-pada-remaja-disurakarta.html.

Chou Hellen pratama. Cyber Smart Parenting. Bandung: Visi Anugerah Indonesia, 2012.

Gustam, Rizky Ramanda. "Karakteristik Media Sosial Dalam Membentuk Budaya Populer Korean Pop Di Kalangan Komunitas Samarinda dan Balikpapan." eJournal Ilmu Komunikasi 3 (2015): 19. Diakses 23 Mei 2019. https://ejournal.ilkom.fisipunmul.ac.id/site/?p=1806

Dhias, Anggarefni Nurmihasti. "Dampak Kegiatan Mengakses Facebook Terhadap Prestasi Belajar Siswa Kompetensi Keahlian Jasa Boga Kelas Xi Di Smk N 3 Wonosari.” Skripsi, UNY, 2015, 1-140. https://eprints.uny.ac.id/26229/.

Darmadi. Pengembangan Model dan Metode Pembelajaran dalam Dinamika Belajar Siswa. Yogyakarta: Deepublish, 2017.

Sitti Nurhalimah. Media Sosial Dan Masyarakat Pesisir: Refleksi Pemikiran Mahasiswa Bidikmisi. Jogyakarta: Deepublish, 2019.

Fa, Chang Khui, dan Liana. Dating Insight - Season 1: Insightful Christian Dating Bible Principle. Bandung: Visi Press, 2014.

Fahmi Gunawan, Dkk. Religion Society dan Social Media. Jogyakarta: Deepublish, 2018. Fernando, Samuel. Bad Habit. Jakarta: Elex Media Komputindo, 2018.

Hakim, Siti Nurina, dan Aliffatullah Alyu Raj. "Dampak Kecanduan Internet (Internet Addiction) Pada Remaja." Prosiding Temu Ilmiah Nasional X Ikatan Psikologi Perkembangan Indonesia 1, no. 0 (22 Agustus 2017). 280 Diakses 25 Juni 2019. http://jurnal.unissula.ac.id/index.php/ippi/article/view/2200.

Hakim, Thirsan. Belajar secara Efektif. Jakarta: Niaga Swadaya, 2005.

Hasanuddin dkk. Anxieties/desires. Jakarta: PT Gramedia Pustaka Utama, 2011. 
Hasmawaty. "Kemampuan Menyimak Anak Melalui Kegiatan Bercerita (Studi Kasus Pada Taman Penitipan Anak Athirah Makassar).” Jurnal Ilmu Teologi dan Pendidikan Agama Kristen 1, no. 1 (Juni 2020): 55-68. https://ojs.sttjaffray.ac.id/jitpk/article/view/463/pdf_4.

Kamus Besar Bahasa Indonesia. Kristiyanto, Daud. "Definisi Kognitif, Afektif, Dan Psikomotorik." Diakses 18 Juli 2019. https://www.academia.edu/9127924/Definisi_Kognitif_Afektif_Dan_Psikomotorik.

Latubessy, Anastasya, dan Ahmad Jazuli. “Analisis Model Penelusuran Backward Chaining dalam Mendeteksi Tingkat Kecanduan Game pada Anak." Jurnal Teknologi dan Sistem Komputer 5, no. 4 (13 Oktober 2017): 129. Diakses 18 Agustus 2019. https://doi.org/10.14710/jtsiskom.5.4.2017.129-134.

Zaiful Rosyid, Mustajab Mansyur, dan Aminol Rosid Abdullah Prestasi Belajar. Malang: Literasi Nusantara, 2019.

Arinda Firdianti. Implementasi Manajemen Berbasis Sekolah Dalam Meningkatkan Prestasi Belajar Siswa. Yogyakarta: Gre Publishing, 2018.

Mahi M. Hikmat. Jurnalistik: Literary Journalism. Jakarta Timur: Kencana, 2018. "Mengenal Sekolah Tinggi Theologia Jaffray Makassar.” Diakses 9 Juli 2019. https://www.sttjaffray.ac.id/profil/mengenal-stt-jaffray.

Nastir. Metodologi Penelitian. Jakarta: Ghalia Indonesia, 1988.

Muhibbin, Syah. Psikologi Belajar. Depok: Rajagrafindo Persada, 2017.

Mustaqim. Psikologi Pendidikan. Yogyakarta: Fakultas Tabiyah Iain Walisongo Semarang, 2008.

Nurhayati, Eti. Psikologi Pendidikan Inovatif. Yogyakarta: Pustaka Pelajar, 2011.

Nurwati, Andi. "Penilaian Ranah Psikomotorik Siswa Dalam Pelajaran Bahasa." Edukasia: Jurnal Penelitian Pendidikan Islam 9, no. 2 (27 September 2014).12. Diakses 18 Juli 2019. https://doi.org/10.21043/edukasia.v9i2.781.

Pransanti, Ditha. "Perubahan Media Komunikasi Dalam Pola Komunikasi Keluarga Di Era Digital." Commed: Jurnal Komunikasi Dan Media 1, no. 1 (17 Juli 2017): 69-81. $\begin{array}{llll}\text { Diakses } & 28 & \text { Febuari }\end{array}$ http://ejournal.upbatam.ac.id/index.php/commed/article/view/115.

Primartiwi, Anggita, dan Agus Naryoso. "Pengaruh Intensitas Mengakses Media Sosial Youtube dan Komunikasi Peer Group Terhadap Prestasi Belajar Siswa." Interaksi Online 7, no. 3 (4 Juli 2019), 158-73. Diakses 4 september 2019. https://ejournal3.undip.ac.id/index.php/interaksi-online/article/view/24132

Pribadi, Benny A. Desain dan Pengembangan Program Pelatihan Berbasis Kompetensi Implementasi Model Addie. Jakarta: Kencana, 2016.

Rahadi, Dedi Rianto. "Perilaku Pengguna Dan Informasi Hoax Di Media Sosial." Jurnal Manajemen Dan Kewirausahaan 5, no. 1 (30 Juni 2017): 58-70. Diakses 5 Juni 2019. https://doi.org/10.26905/jmdk.v5i1.1342.

Ramdhani, Muhamad. "Pengaruh Sosial Media (Facebook) Terhadap Prestasi Belajar Mahasiswa Ilmu Komunikasi Universitas Singaperbangsa (Unsika) Karawang." Jurnal Politikom Indonesiana 1, no. 1 (27 Juli 2016): 66. Diakses 4 September 2019. https://journal.unsika.ac.id/index.php/politikomindonesiana/article/view/325.

Ramadhona, Rossa. 8 Jam Pintar Membuat Kuis Berbasis ICT Bagi Guru. Uwais Inspirasi Indonesia, 2019.

Rismawati, Nadya, dan Gida Kadarisma. "Analisis Motivasi Belajar Terhadap Prestasi Belajar Matematika Siswa Smp.” Journal on Education 1, no. 2 (2018): 491-96. 
Diakses 28 Januari 2019. http://jonedu.org/index.php/joe/article/view/102.

Rohmadi, Arif. Tips Produktif Ber-Social Media. Jakarta: Elex Media Komputindo, 2016. Veithzal. The Economics of Education: Mengelola Pendidikan Secara. Jakarta: Gramedia Pustaka Utama, 2014.

Sari, Ayu Permata, Asmidir Ilyas, dan Ifdil Ifdil. "Tingkat Kecanduan Internet pada

Remaja Awal.” JPPI (Jurnal Penelitian Pendidikan Indonesia) 3, no. 2 (31

Desember 2017) 45. Diakses 20 Mei 2019. https://doi.org/10.29210/02018190.

Sari, Ayu Permata, dan Novera Utami. "Pengaruh Intensitas Penggunaan Internet Terhadap

Prestasi Belajar Siswa Di Sma Negeri 13 Kerinci." Juang: Jurnal Wahana

Konseling 2, no. 1 (28 Maret 2019) 1-12.Diakses 16 Juli 2019.

https://doi.org/10.31851/juang.v2i1.2647.

Sareong, Irene Priskila dan Tri Supartini. "Hubungan Komunikasi Interpersonal Guru dan Siswa Terhadap Keaktifan Belajar Siswa di SMA Kristen Pelita Kasih Makassar." Jurnal Ilmu Teologi dan Pendidikan Agama Kristen 1, no. 1 (Juni 2020): 29-42. https://ojs.sttjaffray.ac.id/jitpk/article/view/466/pdf_2.

Serli dan Hengki Wijaya. "Metode Permainan Dalam Meningkatkan Pemahaman Firman

Tuhan Pada Remaja GKII Okahapi Sumba Timur.” Jurnal Ilmu Teologi dan

Pendidikan Agama Kristen 1, no. 1 (Juni 2020): 17-28.

https://ojs.sttjaffray.ac.id/jitpk/article/view/459/pdf_1.

Soetjipto, Helly P. “Pengujian Validitas Konstruk Kriteria Kecanduan Internet.” Jurnal

Psikologi 32, no. 2 (2005): 74-91-91. Diakses 16 Juli 2019,

https://doi.org/10.22146/jpsi.7072.

Sugiyono. Metode Penelitian Kuantitatif, Kualitatif Dan R \& D. Bandung: Alfabeta, 2015.

Suliswidiawati, Yuli. Menggapai Hidup Bahagia. Jakarta: Elex Media Komputindo, 2015.

Syarbini, Amirulloh. Model Pendidikan Karakter Dalam Keluarga. Jakarta: Elex Media Komputindo, 2014.

Tan, Thomas. Teaching is an Art: Maximize Your Teaching. Jogyakarta: Deepublish, 2017.

"Visi Dan Misi." Diakses 9 Juli 2019. https://www.sttjaffray.ac.id/profil/visi-dan-misi.

Widiana, Herlina Siwi, Sofia Retnowati, dan Rahma Hidayat. "Kontrol Diri Dan Kecenderungan Kecanduan Internet.” Indonesian Psychologycal Journal 1, no. 1 (2004): 6-16. Diakses 15 Juli 2019.

https://eresources.perpusnas.go.id:2217/publications/24526/kontrol-diri-

dankecenderungan-kecanduan-internet.

Widiyanto, Mikha Agus. Statistika Penelitian Bidang Teologi, Pendidikan Agama Kristen, \& Pelayanan Gereja: Lengkap Dengan Konsep Dan Aplikasi SPSS. Bandung: Kalam Hidup, 2014.

Wijaya (ed), Hengki. Metodologi Penelitian Pendidikan Teologi. Makassar: Sekolah Tinggi Theologia Jaffray, 2016.

Ziveria, Mira. "Pemanfaatan Media Sosial Facebook Sebagai Sarana Efektif Pendukung Kegiatan Perkuliahan di Program Studi Sistem Informasi Institut Teknologi dan Bisnis Kalbe" 4 (2017) 10. Diakses 8 Agustus 2019. http://research.kalbis.ac.id/Research/Files/Article/Full/9OCEBKL914ADXEAFCR LZLT2DP.pdf. 